\title{
Sexual Dimorphism in the Multielemental Stoichiometric Phenotypes and Stoichiometric Niches of Spiders
}

\author{
Łukasz Sobczyk ${ }^{(0,}$, Michał Filipiak *(1) and Marcin Czarnoleski \\ Institute of Environmental Sciences, Jagiellonian University, ul. Gronostajowa 7, 30-387 Kraków, Poland; \\ lukasz.sobczyk@uj.edu.pl (Ł.S.); marcin.czarnoleski@uj.edu.pl (M.C.) \\ * Correspondence: michal0filipiak@gmail.com; Tel.: +48-12-664-5134
}

Received: 3 July 2020; Accepted: 29 July 2020; Published: 30 July 2020

check for updates

\begin{abstract}
Nutritional limitations may shape populations and communities of organisms. This phenomenon is often studied by treating populations and communities as pools of homogenous individuals with average nutritional optima and experiencing average constraints and trade-offs that influence their fitness in a standardized way. However, populations and communities consist of individuals belonging to different sexes, each with specific nutritional demands and limitations. Taking this into account, we used the ecological stoichiometry framework to study sexual differences in the stoichiometric phenotypes, reflecting stoichiometric niches, of four spider taxa differing in the hunting mode. The species and sexes differed fundamentally in their elemental phenotypes, including elements beyond those most commonly studied ( $\mathrm{C}, \mathrm{N}$ and $\mathrm{P})$. Both species and sexes were distinguished by the $C: N$ ratio and concentrations of $\mathrm{Cu}, \mathrm{K}$ and $\mathrm{Zn}$. Species additionally differed in concentrations of $\mathrm{Na}, \mathrm{Mg}$ and $\mathrm{Mn}$. Phosphorous was not involved in this differentiation. Sexual dimorphism in spiders' elemental phenotypes, related to differences in their stoichiometric niches, suggests different nutritional optima and differences in nutritional limitation experienced by different sexes and species. This may influence the structure and functioning of spider populations and communities.
\end{abstract}

Keywords: ecological stoichiometry; predator; spider; sex; nutrition; nutritional ecology; arthropod; nutrient cycling; trophic link; food web

\section{Introduction}

1.1. Framework of Ecological Stoichiometry May Be Applied for a Better Understanding of the Ecology and Evolution of Organisms

Energy supply and demand are widely considered to affect the evolution of life histories [1], and to date, many studies have focused on the effects of adaptations on energy balance, the efficiency of energy acquisition and investment, and limits to energy budgets [1-3]. Equally important but less studied is the need to maintain stoichiometric balance [4-6]. Among heterotrophs, the mismatch between the chemical compositions of consumer tissues and consumer food can strongly affect major life history traits (e.g., growth rates, body size, reproductive strategies and survival) [7]. Therefore, the energy-oriented view of the diversity of life is incomplete, as it considers energy budgets as the sole factor limiting the capacity to produce new tissue; luckily, ecological stoichiometry allows for considering both energy and matter in studies related to the ecology and evolution of organisms [4,7-9].

Ecological stoichiometry considers the growth and development of every cell, tissue, organism and population to be subject to the law of conservation of mass [7], which certainly requires myriads of biochemical reactions to be chemically balanced. Within this framework, the concepts of the biogeochemical niche and stoichiometric niche were recently proposed [10,11]. Both concepts similarly 
acknowledge that the availability of particular atoms in specific proportions is a selective factor that affects the evolution of life and the environment (hereafter, the term "stoichiometric niche" will be used). Organismal stoichiometry, also called the elemental phenotype or elementome, determines the organism's demand for resources used for growth and development [11-13] and is highly dependent on the trophic position and phylogeny [14-16]. Following this, the stoichiometric niche is defined as a multivariate niche space occupied by a group of individuals with similar stoichiometric phenotypes, with specific species occupying specific niches $[10,11]$. To obtain stoichiometrically balanced food, various organisms with specific stoichiometric phenotypes might prefer various food sources that provide nutrients in proportions that reflect their nutritional demand $[7,8,13]$. It should be stressed here that a stoichiometric mismatch between the elemental phenotype and food should be primarily considered with reference to the production of new tissue, either the tissue of the organism during growth and development life stages or the tissue of offspring in reproducing organisms. Additionally, more precise evaluations of whether the stoichiometry of food is optimally balanced should not only consider the current chemical composition of the body but also the need to utilize a part of the acquired carbon for ATP production and turnover rates of elements in a tissue. Demand for carbon that covers energetic needs is relatively well studied; for example, research on arthropods suggests that approximately $75 \%$ of carbon in food is respired and released from the body in the form of $\mathrm{CO}_{2}$ [8]. Although obtaining information on the turnover rates of elements is difficult, certain elements should have higher turnover rates compared to other elements and these rates are likely to differ among species [17].

Stoichiometric mismatch between the atomic ratios of an organism's body and its food is expected to have negative fitness consequences $[4,13,18-20]$. Considering the framework of ecological stoichiometry, the quantity of food provided to an organism cannot be a substitute for its quality, and the observed toxic effects of a particular diet on an organism may be caused by stoichiometric mismatch rather than by toxic substances $[5,21]$. The limiting effects of a stoichiometrically unbalanced diet may be scaled-up from individuals to entire communities [7]. In this way, populations and communities of organisms may be shaped by nutritional limitations resulting from stoichiometric mismatches.

\subsection{Sexual Dimorphism in Organismal Stoichiometry Is an Underrated But Important Component of the Functioning of Populations and Communities of Organisms}

Differences in organismal stoichiometry are usually studied by comparing species, but researchers have started to pay attention to the origin of individual variation in the chemical composition of a body, showing that intraspecific differences in organismal stoichiometry may originate from sexual dimorphism, among other sources [22-24]. Such differences are associated with the differential effects on females and males of the processes involved in life history evolution and population dynamics because these effects impose sex-specific nutritional limitations $[13,23,24]$. Therefore, the categorical statement that a species is limited by the nutritional quality of available resources may be disconnected from natural situations, and the results of ecological and evolutionary modeling may be biased if interspecific variability is not considered $[23,25]$. Recently, research has begun to focus on individual variation in the chemical composition of the body, considering that processes involved in life history evolution and population dynamics are likely to differentially affect females and males, imposing sex-specific nutritional limitations; however, such studies are limited in number [13,22-24]. Importantly, by considering such within-species variance, evaluations of resource limitations in a given species increase in ecological relevance.

\subsection{Goal of the Study}

Recent studies have shown that a better understanding of nutritional relations between trophic links in terrestrial communities is needed to explain the observed patterns of trophic interactions. Within this context, it was pointed out: (1) that our knowledge of the nutritional ecology of trophic interactions is biased towards herbivores and omnivores [26], (2) that the need for nutrient regulation 
in carnivores is routinely ignored because predator food is assumed to be of an overall high quality and low nutritional variability [27], (3) that new knowledge on stoichiometric components in predator-prey interactions is needed to connect basic physiological mechanisms underlying predator nutritional needs with prey physiological responses to predation risk and (4) that a deeper understanding of nutritional interactions among species, communities and guilds is needed [26,28]. After 30 years of development of the framework of ecological stoichiometry and almost 20 years after the seminal book of Sterner and Elser [7] was published, data on the elemental phenotypes of a variety of organisms are scarce and lag far behind the data on their genomes [29]. Moreover, arachnids, including spiders, are particularly suited for studies of the general patterns in sexual dimorphism [30,31]. Our work attempts to fill some of the gaps in knowledge mentioned above by considering the stoichiometric relationships between 11 elements composing the bodies of two sexes in different spider taxa, representing different hunting strategies. We studied body stoichiometry in different groups of spiders to address for the first time taxon-specific and sex-specific dimorphism in the multielemental stoichiometric phenotype and stoichiometric niche of spiders with different hunting modes.

\subsection{Hypotheses}

We measured the concentrations of 11 elements (C, N, P, K, Na, Ca, Mg, Fe, Zn, Mn and Cu) in the bodies of both sexes of six spider taxa, each of which had a different hunting strategy (among which four taxa could be used in the following statistical analysis). Processes involved in ecophysiology and life history evolution are likely to differentially affect females and males, imposing sex-specific nutritional limitations and even imposing a conflict between the sexes in reaching sex-specific nutritional optima $[13,23]$. At the same time, stoichiometric phenotypes are species-specific and reflect the nutritional demands of individuals [15,24,32]. Therefore, we hypothesized (1) that taxon-specific and sex-specific differences in the multielemental stoichiometry of the studied spiders and in their stoichiometric niches would be observed. It was previously suggested, considering various organisms beyond spiders, that females have a higher demand for $\mathrm{C}$ and $\mathrm{P}$ than males since the former produce more P-rich nucleic acids and have a greater need for lipids [7,13,33]. Therefore, we hypothesized (2) that sexual dimorphism would be mainly related to larger proportions of $\mathrm{C}$ and $\mathrm{P}$ in the bodies of females than in those of males. Due to the scarcity of related data, it was impossible to hypothesize specific differences related to the body stoichiometry of different spider taxa.

\section{Materials and Methods}

Spiders were collected within the city limits of Kraków, Poland (5003'41"N, $19^{\circ} 56^{\prime} 11^{\prime \prime} \mathrm{E}$; elevation: 219 m.a.s.1.). They represented six hunting models: (1) orb-weaver spiders (Araneidae, genus Araneus), represented by 85 females and 14 males; (2) jumping spiders (Salticidae), represented by 193 individuals (54 males, 44 females and 95 spiders of unrecognized sex); (3) crab spiders (Thomisidae), represented by 326 individuals (unrecognized sex), mainly from the Misumena genus; (4) wolf spiders (Lycosidae), represented by 56 individuals (unrecognized sex); (5) funnel weavers (Agelenidae, genus Tegenaria), represented by 31 females and 15 males and (6) cobweb spiders (Theridiidae, Steatoda grossa), represented by 103 females and 149 males. All the collected individuals were used to prepare analytical samples, for which the measured values of elemental concentrations are presented in Table S1 and Table A1. Ultimately, for the purpose of this study, we analyzed data only for spiders for which we were able to obtain sex-specific analytical measurements, namely, (1) orb-weaver spiders in Araneus, (2) jumping spiders in Salticidae, (5) funnel weavers in Tegenaria and (6) cobweb spiders of Steatoda grossa. Raw data on stoichiometry for the two remaining groups $(3,4)$, for which sex-specific information was not available, were only included in Table A1 for reference. It is important to mention that the reproductive state of collected females was not studied here; thus, females with or without eggs in their bodies could contribute to our samples, which could have increased the variation in the measured concentrations of elements. 
Considering the detection limits of the analytical equipment, we measured the concentrations of the studied elements in samples comprising of one to one hundred individuals, depending on their body mass. The number of individuals comprising every analytical sample is presented in Table A1.

To create analytical samples, spiders were grouped according to sex and species (if identification was possible) or higher taxonomic level (if information on species identity was unavailable). Each sample was freeze-dried, ground and homogenized by a mortar and then freeze-dried again to obtain dry mass for elemental analyses. From each dry mass sample, two analytical subsamples were obtained: (i) a liquid solution subsample used to analyze $\mathrm{K}, \mathrm{Ca}, \mathrm{Mg}, \mathrm{Fe}, \mathrm{Zn}, \mathrm{Mn}, \mathrm{Cu}, \mathrm{Na}$ and $\mathrm{P}$ (hotplate acid digestion with a $4: 1$ solution of nitric acid $(70 \%)$ and hydrogen peroxide $(30 \%)$ ) and (ii) a dry mass subsample used to analyze $\mathrm{C}$ and $\mathrm{N}$. The concentrations of $\mathrm{C}$ and $\mathrm{N}$ were determined with a Vario EL III automatic CHNS analyzer; the concentrations of $\mathrm{K}, \mathrm{Ca}, \mathrm{Mg}, \mathrm{Fe}, \mathrm{Zn}, \mathrm{Mn}, \mathrm{Cu}$ and $\mathrm{Na}$ were determined by atomic absorption spectrometry (Perkin-Elmer AAnalyst 200 and AAnalyst 800); and the concentration of $P$ was determined by colorimetry (MLE FIA flow injection analyzer). Sulfanilic acid was used as the reference material for the $\mathrm{C}$, and $\mathrm{N}$ analyses, and certified reference materials (NCSDC73349, NCSZC73016 and RM8415) were used for the other elements.

Principal component analysis (PCA) was employed to reconstruct the multielemental stoichiometric relations among taxa and sexes using Canoco 5 [34]. The data were log-transformed, centered and standardized by species but not by sample; thus, PCA was performed on a correlation matrix. To check for differences between sexes and taxa, we performed analysis of variance (ANOVA) independently for the 1st- and 2nd-axis scores using Statistica 13 (TIBCO Software Inc.).

\section{Results}

On the plane determined by the first two axes (together explaining $63.19 \%$ of the total variance), spiders largely grouped according to taxon identity and sex (Figure 1 ). The 1st axis was loaded mostly by the variance in $\mathrm{N}$ (loading value: 0.93$), \mathrm{Cu}(0.91), \mathrm{K}(0.84), \mathrm{C}(0.82)$ and $\mathrm{Zn}(0.76$; see Table 1 for more loading values). Following our ANOVA of the 1st axis scores (Table 2), these five elements corresponded the most to the observed differentiation between sexes, with females having higher concentrations of $\mathrm{C}$ and lower concentrations of $\mathrm{N}, \mathrm{Cu}, \mathrm{K}$ and $\mathrm{Zn}$ than males (Figures 1 and 2). The observed pattern was driven principally by the $C: N$ ratio, as shown by the parallel $C$ and $N$ vectors pointing in opposite directions (Figure 1). Therefore, females had significantly higher $C: N$ ratios but not $C: P$ and $N: P$ ratios than males. Similarly, the concentrations of these five elements differed between Steatoda grossa (higher $\mathrm{C}$ concentration and lower concentrations of $\mathrm{N}, \mathrm{Cu}, \mathrm{K}$ and $\mathrm{Zn}$ ) and other taxa of the studied spiders (lower $\mathrm{C}$ concentration and higher concentrations of $\mathrm{N}, \mathrm{Cu}, \mathrm{K}$ and $\mathrm{Zn}$; Figures 1 and 3). The 2 nd axis was loaded primarily by the variance in $\mathrm{Na}$ (loading value: 0.95$), \mathrm{Mn}(0.63)$ and $\mathrm{Mg}$ (0.54; see Table 1 for more loading values). Following our ANOVA of the scores of the 2nd axis (Table 2), these three elements corresponded the most to the observed differentiation between taxa, with Steatoda grossa and Tegenaria having higher body concentrations of $\mathrm{Na}$ and $\mathrm{Mg}$ but lower concentrations of Mn than Araneus and Salticidae (Figures 1 and 4). 


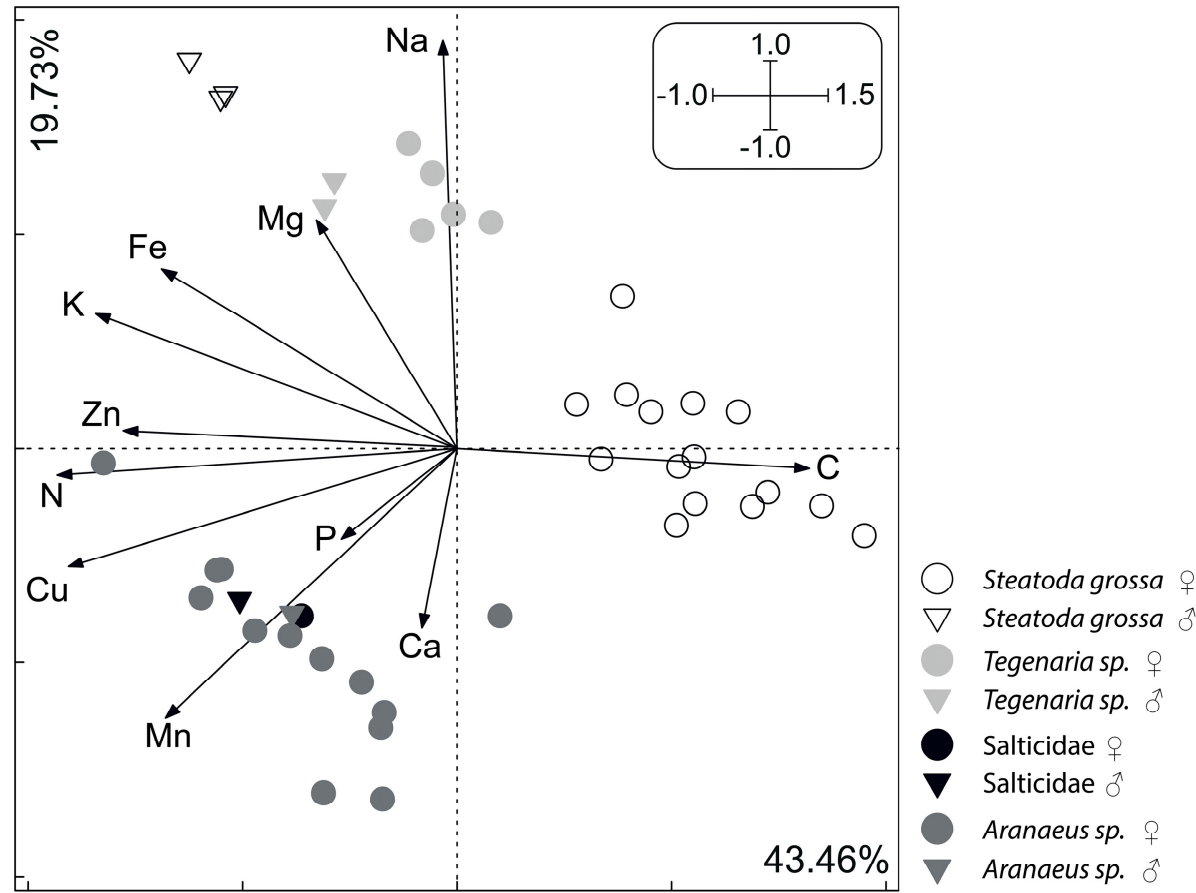

Figure 1. Principal component analysis (PCA) plot-multivariate analysis of stoichiometric relations in spider taxa and sexes. The first two axes are presented. Considering the 1st axis, females are separated from males primarily due to their relatively high concentration of $\mathrm{C}$ and low concentrations of $\mathrm{N}, \mathrm{Cu}, \mathrm{K}$ and $\mathrm{Zn}$ (see Table 2 and Figure 2 for detailed statistics). Similarly, Steatoda grossa is separated from the other taxa due to its relatively high concentration of $\mathrm{C}$ and low concentrations of $\mathrm{N}, \mathrm{Cu}, \mathrm{K}$ and $\mathrm{Zn}$ (the other taxa do not differ statistically from each other; see Table 2 and Figure 3 for statistics). Considering the 2 nd axis, Tegenaria sp. forms a separate cluster mainly due to its relatively high concentrations of $\mathrm{Na}$ and $\mathrm{Mg}$ and low concentration of Mn. An opposite tendency is observed for Araneus sp., while Steatoda grossa together with Salticidae forms one cluster with intermediate concentrations of $\mathrm{Na}, \mathrm{Mg}$ and $\mathrm{Mn}$. These tendencies were confirmed by ANOVA performed independently for the 1st and 2 nd axis scores ( $p<0.05$; Figures $2-4)$.

Table 1. Loadings values for all elements used in the PCA that variously contributed to the pattern observed in Figure 1. The mark '- ' denotes vectors' directions.

\begin{tabular}{ccc}
\hline & Axis 1 & Axis 2 \\
\hline $\mathrm{Ca}$ & -0.08 & -0.42 \\
$\mathrm{Cu}$ & -0.91 & -0.28 \\
$\mathrm{Fe}$ & -0.69 & 0.42 \\
$\mathrm{Mg}$ & -0.33 & 0.54 \\
$\mathrm{Mn}$ & -0.68 & -0.63 \\
$\mathrm{~K}$ & -0.84 & 0.31 \\
$\mathrm{Na}$ & -0.03 & 0.95 \\
$\mathrm{Zn}$ & -0.76 & 0.04 \\
$\mathrm{P}$ & -0.27 & -0.21 \\
$\mathrm{~N}$ & -0.93 & -0.06 \\
$\mathrm{C}$ & 0.82 & -0.05 \\
\hline
\end{tabular}


Table 2. Two-way ANOVA performed separately for 1st and 2nd axis scores. Statistically significant results are bolded.

\begin{tabular}{cccccc}
\hline 1st Axis & Df & SS & MS & F & $p$ \\
\hline Taxon & $\mathbf{3}$ & $\mathbf{4 . 2 5}$ & $\mathbf{1 . 4 2}$ & $\mathbf{3 . 7 8}$ & $\mathbf{0 . 0 2}$ \\
Sex & $\mathbf{1}$ & $\mathbf{1 . 6 7}$ & $\mathbf{1 . 6 7}$ & $\mathbf{4 . 4 6}$ & $\mathbf{0 . 0 4}$ \\
Taxon $\times$ Sex & 3 & 2.57 & 0.86 & 2.28 & 0.10 \\
Error & 34 & 12.75 & 0.37 & & \\
Total & 41 & 42.00 & & & \\
\hline 2nd Axis & Df & SS & MS & F & $p$ \\
\hline Taxon & $\mathbf{3}$ & $\mathbf{1 4 . 5 8}$ & $\mathbf{4 . 8 6}$ & $\mathbf{1 8 . 7 0}$ & $<\mathbf{0 . 0 0 0 0 1}$ \\
\hline Sex & 1 & 0.51 & 0.51 & 1.98 & 0.17 \\
\hline Taxon $\times$ Sex & 3 & 1.81 & 0.60 & 2.32 & 0.09 \\
\hline Error & 34 & 8.84 & 0.26 & & \\
\hline Total & 41 & 42.00 & & &
\end{tabular}

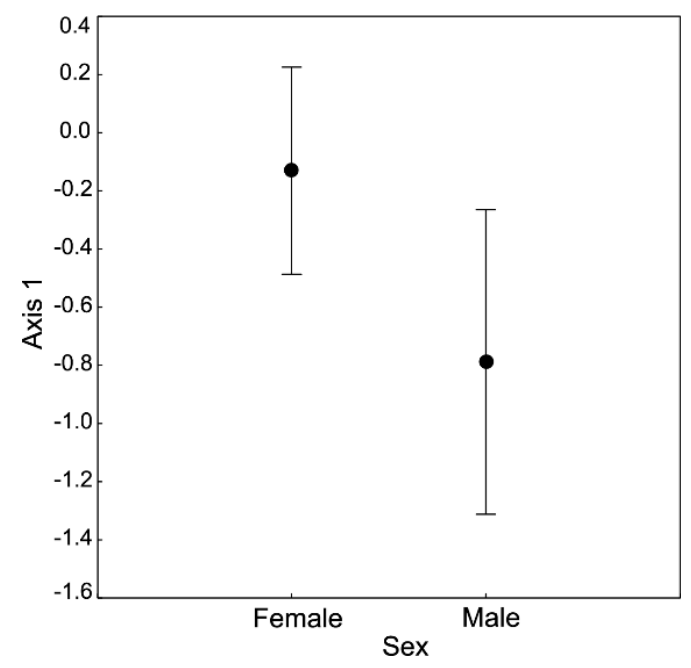

Figure 2. Multivariate analysis of stoichiometric relations in two sexes of spiders (PCA). ANOVA performed for the 1 st axis scores $(\mathrm{F}=4.46, p=0.04)$. Bars denote the confidence intervals. Table 1 provides information on the contribution of different elements to the scores of Axis 1.

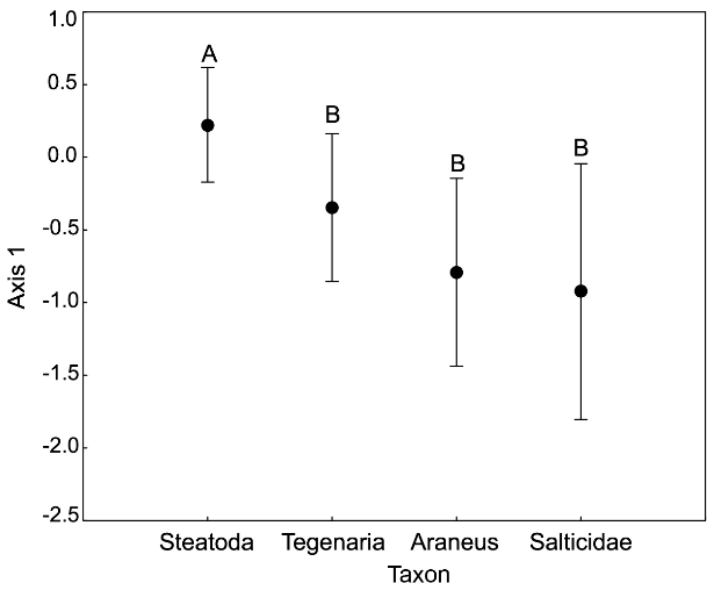

Figure 3. Multivariate analysis of stoichiometric relations in the four taxa of spiders (PCA). ANOVA performed for the 1st axis scores. Different letters denote significant differences in multielemental stoichiometry between taxa $(\mathrm{F}=18.70, p=0.02)$. Bars denote the confidence intervals. Table 1 provides information on the contribution of different elements to the scores of Axis 1. 


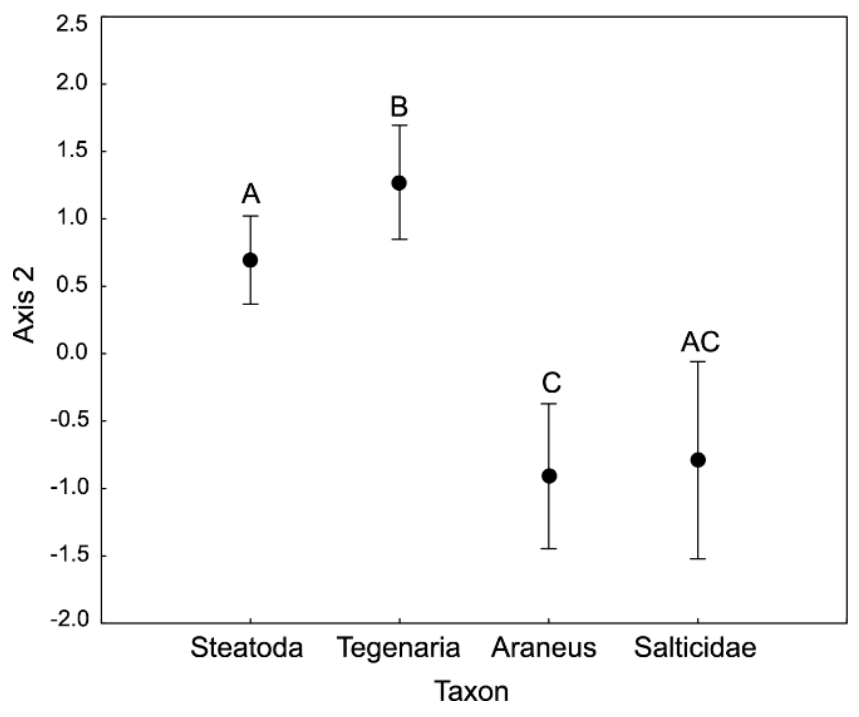

Figure 4. Multivariate analysis of stoichiometric relations in the four taxa of spiders (PCA). ANOVA performed for the 2 nd axis scores. Different letters denote significant differences in multielemental stoichiometry between taxa $(\mathrm{F}=3.78, p<0.00001)$. Bars denote the confidence intervals. Table 1 provides information on the contribution of different elements to the scores of Axis 2.

\section{Discussion}

Our results supported hypothesis (1), i.e., the view that stoichiometric phenotypes differ not only among taxonomic groups but also between sexes. This suggests that different taxa as well as different sexes tend to occupy distinct multielemental stoichiometric niches. Importantly, the nature of stoichiometric differences between sexes was similar among spider taxa, irrespective of their hunting modes. In particular, females were characterized by a higher concentration of $C$ and lower concentrations of $\mathrm{N}, \mathrm{Cu}, \mathrm{K}$ and $\mathrm{Zn}$ than males. This pattern was shaped mostly by the $\mathrm{C}: \mathrm{N}$ ratio, which was higher for females than for males. Since the P concentration was similar in the bodies of both sexes, we found only partial support for hypothesis (2); i.e., females had a higher concentration of $C$ in their bodies than males, but the $\mathrm{P}$ concentration was similar between the sexes; additionally (which was not hypothesized), females had lower concentrations of $\mathrm{N}, \mathrm{Cu}, \mathrm{K}$ and $\mathrm{Zn}$ than males. Importantly, we have shown that multiple elements beyond $\mathrm{C}, \mathrm{N}$ and $\mathrm{P}$ shape stoichiometric niches.

To date, it has been shown that spider species specializing in different web architectures differ in body stoichiometry regarding C:N and N:P ratios but not the C:P ratio and in the concentration of $\mathrm{N}$ but not $\mathrm{C}$ or $\mathrm{P}$ [35]. Our results conform to these findings by showing stoichiometric differences among spiders having different hunting strategies, including those building webs and hunting without webs. In our study, similar to the findings of Ludwig and colleagues [35], spider species differed mainly due to different $\mathrm{C}: \mathrm{N}$ ratios; however, we show that the stoichiometric niche of the species was more complex and additionally structured by concentrations of $\mathrm{Cu}, \mathrm{K}, \mathrm{Zn}, \mathrm{Na}, \mathrm{Mg}$ and $\mathrm{Mn}$. Interestingly, we found that $S$. grossa females had exceptionally high C:N and C:Zn ratios compared with other studied spiders, and increased in the C:other elements ratio could reflect rich fat deposits in a body. However, increased fat deposition should result in a proportional increase of the ratio of $C$ to all other elements, which is not reflected in our results. The observed pattern could reflect additional factors, including a specific reproductive stage of S. grossa individuals, e.g., the investment in egg production. Undoubtedly, future studies should more directly address how reproductive states affect the elemental content of the body. What is exceptionally interesting is that sex differences are similarly driven mainly by differences in the $C: N$ ratio (higher in females), followed by differences in the concentrations of $\mathrm{Cu}, \mathrm{K}$ and $\mathrm{Zn}$. Additionally, the sexual differences in spiders' stoichiometric phenotypes differed from multielemental phenotypes reported for other arthropods, i.e., two bee species [24,36] and three species of beetles [37]. Therefore, a multielemental picture of stoichiometric differences between sexes 
may be taxonomically specific and/or feeding-guild-specific rather than uniform among taxonomical groups and/or feeding guilds. We conclude that in studies dealing with ecological stoichiometry, samples should be divided according to sex because under/overrepresentation of a specific sex may influence the results. Importantly, the observed patterns suggest that stoichiometric relations between atoms of more elements than the commonly studied C, N and P may shape ecological interactions and the functioning of food webs, which is also confirmed by the results of the limited studies on multielemental ecological stoichiometry published to date (e.g., [8,24,38]). Recently, the role of $\mathrm{Na}$ limitation in shaping ecological interactions was emphasized [39]; however, approximately twenty-five elements build molecules driving the functioning of every living organism on Earth, and much research is still needed in the area of multielemental stoichiometry $[5,8,29]$. This is made even more complicated by the fact that the concentration of every element composing the organismal body influences the concentrations of all other elements, and all of them are strongly interrelated [38]. Therefore, it is essential to consider multielemental ratios in studies dealing with ecological stoichiometry.

Only a few studies to date have considered the ecological stoichiometry and elemental nutrition of spiders (e.g., [32,35,40-42]); therefore, a large gap in data exists, and it is hard to perform comparisons leading to strong and meaningful conclusions. Hence, we will supplement our reasoning with available data collected for other arthropods. A study on different "populations" (natural and reared in the laboratory) of the black widow spider Latrodectus hesperus suggested between-"population" differences in C:N, C:P and N:P stoichiometries [40]. However, only female spiders were considered. Our current study does not allow us to compare variation in stoichiometric phenotypes between sexes because of the too small number of analytical samples collected for males; however, it was previously shown, using solitary bees as model organisms, that females are more homeostatic than males in their elemental phenotype [24]. If so, it may be possible to find statistically significant differences in stoichiometric phenotypes of females but not males associated with different populations. Considering that sexual dimorphism may apply to both the specific stoichiometric phenotype and the level of homeostasis of this phenotype, we conclude that the results obtained for only one sex should not be approximated to the whole population.

Different sexes are exposed to distinct selection pressures posing sex-specific constraints on individuals and have different nutritional optima, and they may even experience conflicting selection pressures $[43,44]$. Moreover, food quality may drive sexually different selection pressures to a greater extent than food quantity, since definite nutrients in exact proportions are needed to build particular body structures $[13,23,45]$. Correspondingly, we observed fundamental differences in the elemental phenotype between male and female spiders, which might suggest sex-specific challenges in the environment and thus selection pressures. This observation means that the two sexes of spiders might differ in a stoichiometric niche that reflects sex-specific nutritional demands. Therefore, different proportions of nutrients in food might be optimal for females and males. This finding has important implications for studying the ecology and evolution of sexual dimorphism. Considering nutrition, many animals are known to sexually differ in their trophic behavior (e.g., foraging for different foods), morphology (e.g., specialized morphological structures) or physiology (e.g., males do not eat at all), which are all expressed as easily observable traits [46]. Our study shows that these differences may be ecologically and evolutionarily relevant even if they are imperceptible, similar to the example of differences in stoichiometric niches. Stoichiometric niches induce resource competition, resulting in nutritional limitation that in turn shapes populations and communities of organisms [7]. However, most stoichiometrically explicit models do not consider population and community structure, where intraspecific variability in elemental stoichiometry exists [43,47-49]. Concurrently, organismal fitness may be influenced by trade-offs originating from the conflict between the sexes in reaching sex-specific nutritional optima $[22,23,50]$. Hence, the observed sexual dimorphism in stoichiometric niches may shape spider population structure via the nutritional quality of available food.

Our results also have implications for the conservation biology of spiders. Recently, it was suggested that spiders are threatened by human-induced erosion of trophic webs [51]. Nyffeler and 
Bonte [51] found a dramatic population density decline for the spider Araneus diadematus in Swiss Midlands and discussed the ongoing abundance decline of spiders and other insectivorous animals. They related the decline in spider abundance to the decline in insect abundance. Our study suggests a more complicated picture, where the direct driver of spider decline is not the total insect decline but declines in the proportions of specific spider food sources that are stoichiometrically balanced for spiders and part of sex-specific and species-specific stoichiometric niches.

\section{Conclusions}

Populations are not homogenous but consist of individuals belonging to different sexes, which have distinct stoichiometric niches. Intraspecific variability in elemental stoichiometry has rarely been studied, and most stoichiometrically explicit models treat populations/communities as pools of uniform elements, ignoring natural population/community structure. Therefore, we predict that underestimating variability among individuals in populations might influence conclusions about the outcomes of resource limitation in nature. At the same time, the conflict between sexes in reaching sex-specific nutritional optima or stoichiometric constraints posed on a single sex may be crucial for population growth. We believe that considering such within-species variance will make evaluations of resource limitations in a given species more ecologically relevant. Moreover, multielemental stoichiometry beyond C:N:P should be considered to fully understand the complex relationships of the ratios of all 25 (approximately) atoms building the physiological machinery and morphological traits of every organism on the planet.

Supplementary Materials: The following are available online at http://www.mdpi.com/2075-4450/11/8/484/s1, Table S1: Concentrations of elements in 6 spider taxa-all raw data collected.

Author Contributions: Conceptualization, M.F., Ł.S., and M.C.; methodology, Ł.S., M.C. and M.F.; validation, Ł.S. and M.C.; formal analysis, Ł.S.; investigation, Ł.S., M.F. and M.C.; resources, Ł.S. and M.F.; data curation, Ł.S.; writing—original draft preparation, M.F.; writing—review and editing, M.C. and Ł.S.; visualization, Ł.S.; supervision, M.C. All authors have read and agreed to the published version of the manuscript.

Funding: This research was funded by Jagiellonian University, Faculty of Biology (N18/DBS/000003) and the National Science Centre (Grant No. 2011/01/B/NZ8/00103).

Acknowledgments: We thank Anna Rożen for helping with sample collection.

Conflicts of Interest: The authors declare no conflict of interest. 


\section{Appendix A}

Table A1. Concentrations and C:N:P molar ratios for all six species of spiders with different hunting strategies. All raw data were collected; $n=$ number of individuals per analytical sample. See the Table S1 for a user-friendly Excel file.

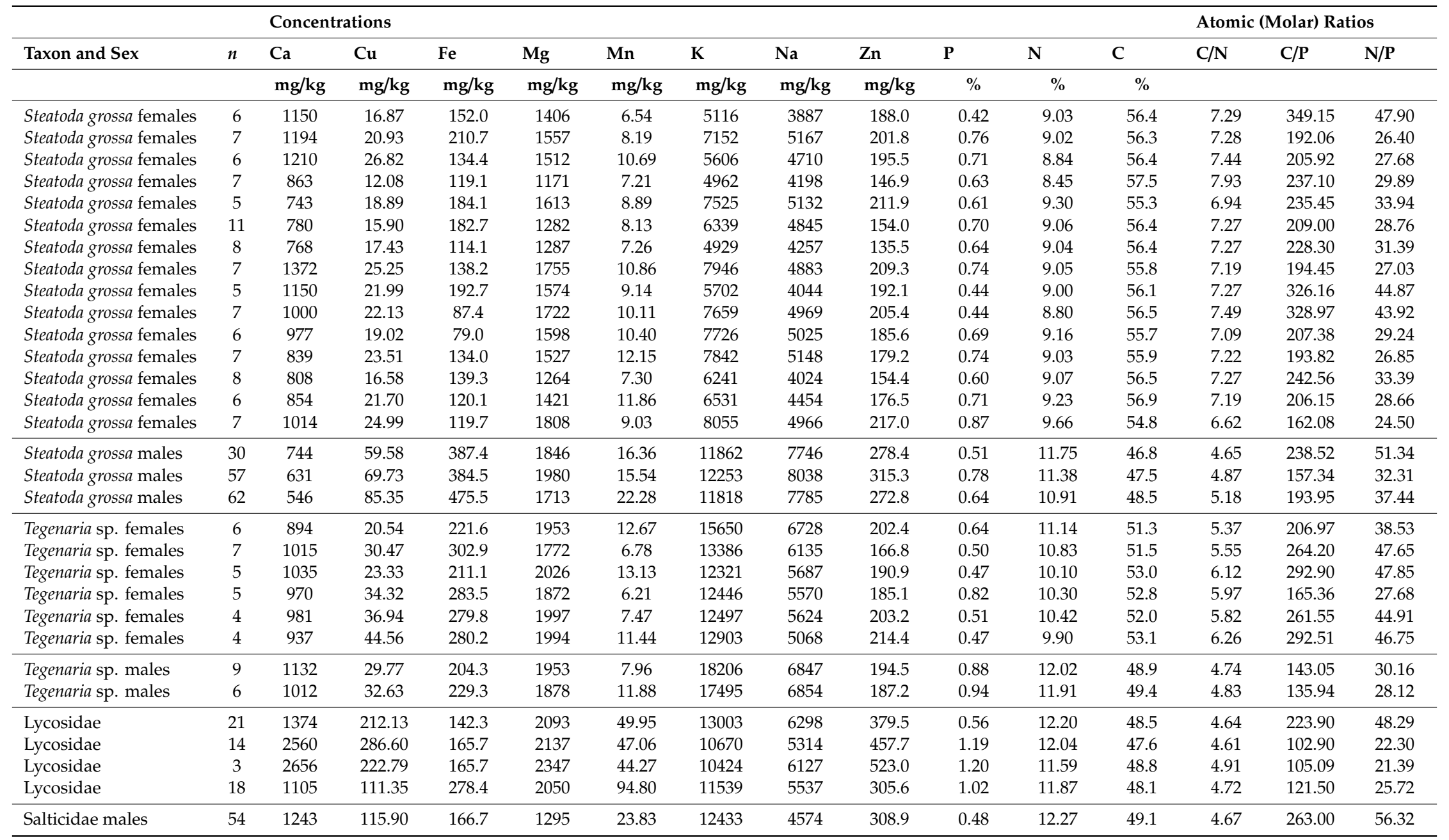


Table A1. Cont.

\begin{tabular}{|c|c|c|c|c|c|c|c|c|c|c|c|c|c|c|c|}
\hline \multirow[b]{2}{*}{ Taxon and Sex } & \multicolumn{4}{|c|}{ Concentrations } & \multirow[b]{2}{*}{$\mathrm{Mg}$} & \multirow[b]{2}{*}{ Mn } & \multirow[b]{2}{*}{$\mathbf{K}$} & \multirow[b]{2}{*}{$\mathrm{Na}$} & \multirow[b]{2}{*}{$\mathrm{Zn}$} & \multirow[b]{2}{*}{$\mathbf{P}$} & \multirow[b]{2}{*}{$\mathbf{N}$} & \multirow[b]{2}{*}{ C } & \multicolumn{3}{|c|}{ Atomic (Molar) Ratios } \\
\hline & $n$ & $\mathrm{Ca}$ & $\mathrm{Cu}$ & $\mathrm{Fe}$ & & & & & & & & & $\mathrm{C} / \mathrm{N}$ & $\mathbf{C} / \mathrm{P}$ & $\mathbf{N} / \mathbf{P}$ \\
\hline & & $\mathrm{mg} / \mathrm{kg}$ & $\mathrm{mg} / \mathrm{kg}$ & $\mathrm{mg} / \mathrm{kg}$ & $\mathrm{mg} / \mathrm{kg}$ & $\mathrm{mg} / \mathrm{kg}$ & $\mathrm{mg} / \mathrm{kg}$ & $\mathrm{mg} / \mathrm{kg}$ & $\mathrm{mg} / \mathrm{kg}$ & $\%$ & $\%$ & $\%$ & & & \\
\hline Salticidae females & 44 & 929 & 88.34 & 183.6 & 1201 & 24.80 & 12776 & 4131 & 302.6 & 0.76 & 10.97 & 51.7 & 5.50 & 176.49 & 32.11 \\
\hline $\begin{array}{l}\text { Salticidae males and } \\
\text { females }\end{array}$ & 95 & 1217 & 108.55 & 469.0 & 1295 & 27.16 & 12485 & 4585 & 396.5 & 0.45 & 11.92 & 59.0 & 5.77 & 338.23 & 58.62 \\
\hline Thomisidae & 14 & 2617 & 135.78 & 167.8 & 2352 & 51.95 & 12294 & 3828 & 523.7 & 1.11 & 12.22 & 48.4 & 4.62 & 112.83 & 24.44 \\
\hline Thomisidae & 51 & 1001 & 68.54 & 129.9 & 1964 & 36.10 & 14872 & 4253 & 397.4 & 1.21 & 12.27 & 66.5 & 6.32 & 141.83 & 22.43 \\
\hline Thomisidae & 21 & 762 & 52.96 & 163.2 & 1348 & 23.64 & 12939 & 4098 & 178.6 & 0.52 & 12.91 & 49.2 & 4.44 & 243.33 & 54.77 \\
\hline Thomisidae & 40 & 1919 & 105.80 & 130.5 & 2085 & 44.04 & 11743 & 3472 & 356.3 & 1.07 & 11.96 & 48.8 & 4.76 & 117.21 & 24.60 \\
\hline Thomisidae & 100 & 1015 & 104.06 & 122.8 & 1502 & 37.35 & 12218 & 3514 & 191.8 & 0.59 & 12.25 & 48.1 & 4.58 & 209.86 & 45.86 \\
\hline Thomisidae & 100 & 805 & 87.24 & 119.5 & 2062 & 48.37 & 12597 & 3779 & 569.7 & 1.10 & 12.10 & 47.9 & 4.62 & 112.57 & 24.38 \\
\hline Araneus sp. females & 4 & 861 & 87.23 & 313.5 & 1339 & 27.32 & 12124 & 4124 & 224.8 & 1.06 & 12.54 & 49.0 & 4.55 & 119.58 & 26.25 \\
\hline Araneus sp. females & 8 & 1371 & 104.34 & 520.9 & 1677 & 34.22 & 14795 & 4234 & 298.8 & 0.46 & 12.50 & 48.3 & 4.51 & 270.33 & 59.95 \\
\hline Araneus sp. females & 1 & 887 & 61.71 & 159.5 & 1449 & 73.76 & 8100 & 2620 & 236.5 & 0.50 & 10.79 & 51.2 & 5.54 & 263.71 & 47.61 \\
\hline Araneus sp. females & 3 & 1312 & 64.91 & 182.5 & 1625 & 44.73 & 8771 & 3149 & 199.9 & 0.60 & 10.81 & 50.7 & 5.47 & 216.46 & 39.57 \\
\hline Araneus sp. females & 4 & 931 & 50.27 & 156.4 & 1495 & 38.26 & 9513 & 3110 & 207.6 & 0.90 & 10.94 & 50.1 & 5.34 & 143.82 & 26.95 \\
\hline Araneus sp. females & 5 & 1197 & 61.46 & 167.4 & 1897 & 50.64 & 10081 & 3007 & 179.1 & 0.58 & 11.09 & 49.6 & 5.22 & 221.53 & 42.44 \\
\hline Araneus sp. females & 5 & 993 & 50.99 & 164.0 & 1748 & 37.85 & 9691 & 3467 & 217.8 & 0.57 & 11.42 & 68.4 & 6.98 & 307.84 & 44.09 \\
\hline Araneus sp. females & 6 & 1008 & 54.88 & 156.8 & 1756 & 33.77 & 12038 & 3431 & 236.7 & 1.10 & 11.38 & 49.1 & 5.04 & 115.33 & 22.90 \\
\hline Araneus sp. females & 7 & 1360 & 64.08 & 202.7 & 1727 & 47.35 & 12730 & 3834 & 205.3 & 0.75 & 11.86 & 47.6 & 4.68 & 164.35 & 35.11 \\
\hline Araneus sp. females & 9 & 913 & 59.95 & 176.4 & 1502 & 36.28 & 10775 & 3313 & 226.3 & 0.81 & 11.43 & 49.2 & 5.02 & 155.74 & 31.03 \\
\hline Araneus sp. females & 10 & 995 & 67.41 & 187.6 & 1755 & 46.58 & 13533 & 4053 & 234.7 & 0.88 & 12.31 & 48.1 & 4.56 & 140.89 & 30.88 \\
\hline Araneus sp. females & 15 & 1270 & 64.75 & 203.9 & 1782 & 49.78 & 13865 & 3854 & 250.9 & 0.71 & 12.05 & 47.2 & 4.57 & 170.68 & 37.37 \\
\hline Araneus sp. females & 8 & 1648 & 71.40 & 305.8 & 1557 & 40.60 & 10005 & 2847 & 183.2 & 1.02 & 10.47 & 50.1 & 5.58 & 126.90 & 22.73 \\
\hline Araneus sp. males & 14 & 697 & 66.14 & 229.4 & 1077 & 21.99 & 9055 & 3950 & 251.2 & 0.87 & 12.36 & 46.0 & 4.35 & 137.16 & 31.56 \\
\hline
\end{tabular}




\section{References}

1. Stearns, S.C. The Evolution of Life Histories; Oxford University Press: Oxford, UK, 1996.

2. Kozłowski, J. Why life histories are diverse. Pol. J. Ecol. 2006, 54, 585-605.

3. Ejsmond, M.J.; Varpe, Ø.; Czarnoleski, M.; Kozłowski, J. Seasonality in offspring value and trade-offs with growth explain capital breeding. Am. Nat. 2015, 186, E111-E125. [CrossRef]

4. Filipiak, M.; Weiner, J. Plant-insect interactions: The role of ecological stoichiometry. Acta Agrobot. 2017, 70, 1-16. [CrossRef]

5. Filipiak, M. A better understanding of bee nutritional ecology is needed to optimize conservation strategies for wild bees-the application of ecological stoichiometry. Insects 2018, 9, 85. [CrossRef] [PubMed]

6. Hall, S.R. Stoichiometrically explicit food webs: Feedbacks between resource supply, elemental constraints, and species diversity. Annu. Rev. Ecol. Evol. Syst. 2009, 40, 503-528. [CrossRef]

7. Sterner, R.W.; Elser, J.J. Ecological Stoichiometry: The Biology of Elements from Molecules to the Biosphere; Princeton University Press: Princeton, NJ, USA, 2003.

8. Filipiak, M. Nutrient dynamics in decomposing dead wood in the context of wood eater requirements: The ecological stoichiometry of saproxylophagous insects. In Saproxylic Insects Diversity, Ecology and Conservation; Ulyshen, M., Ed.; Springer International Publishing: Heidelberg, Germany, 2018; pp. 429-469.

9. Swanson, E.M.; Espeset, A.; Mikati, I.; Bolduc, I.; Kulhanek, R.; White, W.A.; Kenzie, S.; Snell-Rood, E.C. Nutrition shapes life-history evolution across species. Proc. R. Soc. B Biol. Sci. 2016, 283, 20152764. [CrossRef]

10. González, A.L.; Dézerald, O.; Marquet, P.A.; Romero, G.Q.; Srivastava, D.S. The multidimensional stoichiometric niche. Front. Ecol. Evol. 2017, 5, 1-17. [CrossRef]

11. Peñuelas, J.; Fernández-Martínez, M.; Ciais, P.; Jou, D.; Piao, S.; Obersteiner, M.; Vicca, S.; Janssens, I.A.; Sardans, J. The bioelements, the elementome, and the biogeochemical niche. Ecology 2019, 100, e02652. [CrossRef]

12. Jeyasingh, P.D.; Cothran, R.D.; Tobler, M. Testing the ecological consequences of evolutionary change using elements. Ecol. Evol. 2014, 4, 528-538. [CrossRef]

13. Kay, A.D.; Ashton, I.W.; Gorokhova, E.; Kerkhoff, A.J.; Liess, A.; Litchman, E. Toward a stoichiometric framework for evolutionary biology. Oikos 2005, 109, 6-17. [CrossRef]

14. Bartrons, M.; Sardans, J.; Hoekman, D.; Peñuelas, J. Trophic transfer from aquatic to terrestrial ecosystems: A test of the biogeochemical niche hypothesis. Ecosphere 2018, 9, e02338. [CrossRef]

15. González, A.L.; Céréghino, R.; Dézerald, O.; Farjalla, V.F.; Leroy, C.; Richardson, B.A.; Richardson, M.J.; Romero, G.Q.; Srivastava, D.S. Ecological mechanisms and phylogeny shape invertebrate stoichiometry: A test using detritus-based communities across Central and South America. Funct. Ecol. 2018, 32, 2448-2463. [CrossRef]

16. Leal, M.C.; Seehausen, O.; Matthews, B. The ecology and evolution of stoichiometric phenotypes. Trends Ecol. Evol. 2017, 32, 108-117. [CrossRef] [PubMed]

17. da Silva, J.J.R.F.; Williams, R.J.P. The Biological Chemistry of the Elements. The Inorganic Chemistry of Life; Oxford University Press: Oxford, UK, 2001.

18. Denno, R.F.; Fagan, W.F. Might nitrogen limitation promote omnivory among carnivorous arthropods? Ecology 2003, 84, 2522-2531. [CrossRef]

19. Kay, A.D.; Vrede, T. Evolutionary and biochemical aspects. In Encyclopedia of Ecology; Jørgensen, S.E., Fath, B.D., Eds.; Elsevier: Oxford, UK, 2008; pp. 1472-1481.

20. Filipiak, M. Pollen stoichiometry may influence detrital terrestrial and aquatic food webs. Front. Ecol. Evol. 2016, 4, 1-8. [CrossRef]

21. Jones, R.H.; Flynn, K.J. Nutritional status and diet composition affect the value of diatoms as Copepod Prey. Science 2005, 307, 1457-1459. [CrossRef]

22. Goos, J.M.; Cothran, R.D.; Jeyasingh, P.D. Within-population variation in the chemistry of life: The stoichiometry of sexual dimorphism in multiple dimensions. Evol. Ecol. 2017, 31, 635-651. [CrossRef]

23. Morehouse, N.I.; Nakazawa, T.; Booher, C.M.; Jeyasingh, P.D.; Hall, M.D. Sex in a material world: Why the study of sexual reproduction and sex-specific traits should become more nutritionally-explicit. Oikos 2010, 119, 766-778. [CrossRef]

24. Filipiak, M. Key pollen host plants provide balanced diets for wild bee larvae: A lesson for planting flower strips and hedgerows. J. Appl. Ecol. 2019, 56, 1410-1418. [CrossRef] 
25. Richard, R.; de Roos, A.M. The impact of development on patterns of nutrient limitation. Funct. Ecol. 2018, 32, 1507-1519. [CrossRef]

26. Wilder, S.M. Spider nutrition: An integrative perspective. Adv. Insect Physiol. 2011, 40, 87-136. [CrossRef]

27. Wilder, S.M.; Norris, M.; Lee, R.W.; Raubenheimer, D.; Simpson, S.J. Arthropod food webs become increasingly lipid-limited at higher trophic levels. Ecol. Lett. 2013, 16, 895-902. [CrossRef] [PubMed]

28. Simpson, S.J.; Raubenheimer, D.; Charleston, M.A.; Clissold, F.J. Modelling nutritional interactions: From individuals to communities. Trends Ecol. Evol. 2010, 25, 53-60. [CrossRef] [PubMed]

29. Kaspari, M.; Powers, J.S. Biogeochemistry and geographical ecology: Embracing all twenty-five elements required to build organisms. Am. Nat. 2016, 188, S62-S73. [CrossRef]

30. McLean, C.J.; Garwood, R.J.; Brassey, C.A. Sexual dimorphism in the Arachnid orders. PeerJ 2018, 6, e5751. [CrossRef]

31. Cordellier, M.; Schneider, J.M.; Uhl, G.; Posnien, N. Sex differences in spiders: From phenotype to genomics. Dev. Genes Evol. 2020, 230, 155-172. [CrossRef]

32. Wilder, S.M.; Barnes, C.L.; Hawlena, D. Predicting predator nutrient intake from prey body contents. Front. Ecol. Evol. 2019, 7, 42. [CrossRef]

33. Markow, T.A.; Raphael, B.; Dobberfuhl, D.; Breitmeyer, C.M.; Elser, J.J.; Pfeiler, E. Elemental stoichiometry of Drosophila and their hosts. Funct. Ecol. 1999, 13, 78-84. [CrossRef]

34. Smilauer, P.; Lepš, J. Multivariate Analysis of Ecological Data Using CANOCO 5; Cambridge University Press: Cambridge, UK, 2014.

35. Ludwig, L.; Barbour, M.A.; Guevara, J.; Avilés, L.; González, A.L. Caught in the web: Spider web architecture affects prey specialization and spider-prey stoichiometric relationships. Ecol. Evol. 2018, 8, 6449-6462. [CrossRef]

36. Filipiak, M.; Kuszewska, K.; Asselman, M.; Denisow, B.; Stawiarz, E.; Woyciechowski, M.; Weiner, J. Ecological stoichiometry of the honeybee: Pollen diversity and adequate species composition are needed to mitigate limitations imposed on the growth and development of bees by pollen quality. PLoS ONE 2017, 12, e0183236. [CrossRef]

37. Filipiak, M.; Weiner, J. How to make a beetle out of wood: Multi-elemental stoichiometry of wood decay, xylophagy and fungivory. PLoS ONE 2014, 9, e115104. [CrossRef] [PubMed]

38. Jeyasingh, P.D.; Goos, J.M.; Lind, P.R.; Chowdhury, P.R.; Sherman, R.E. Phosphorus supply shifts the quotas of multiple elements in algae and Daphnia: Ionomic basis of stoichiometric constraints. Ecol. Lett. 2020, 23, 1064-1072. [CrossRef] [PubMed]

39. Kaspari, M. The seventh macronutrient: How sodium shortfall ramifies through populations, food webs and ecosystems. Ecol. Lett. 2020, 23, 1153-1168. [CrossRef]

40. Trubl, P.; Johnson, J.C. Ecological stoichiometry of the black widow spider and its prey from desert, urban and laboratory populations. J. Arid Environ. 2019, 163, 18-25. [CrossRef]

41. Barnes, C.L.; Hawlena, D.; McCue, M.D.; Wilder, S.M. Consequences of prey exoskeleton content for predator feeding and digestion: Black widow predation on larval versus adult mealworm beetles. Oecologia 2018, 190, 1-9. [CrossRef] [PubMed]

42. Barnes, C.L.; Hawlena, D.; Wilder, S.M. Predators buffer the effects of variation in prey nutrient content for nutrient deposition. Oikos 2018, 128, 360-367. [CrossRef]

43. Zajitschek, F.; Connallon, T. Partitioning of resources: The evolutionary genetics of sexual conflict over resource acquisition and allocation. J. Evol. Biol. 2017, 30, 826-838. [CrossRef]

44. Rostant, W.G.; Mason, J.S.; de Coriolis, J.C.; Chapman, T. Resource-dependent evolution of female resistance responses to sexual conflict. Evol. Lett. 2020, 4, 54-64. [CrossRef]

45. Simpson, S.J.; Raubenheimer, D. The nature of nutrition: A unifying framework. Aust. J. Zool. 2011, 59, 350. [CrossRef]

46. Shine, R. Ecological causes for the evolution of sexual dimorphism: A review of the evidence. Q. Rev. Biol. 1989, 64, 419-461. [CrossRef]

47. Prater, C.; Wagner, N.D.; Frost, P.C. Interactive effects of genotype and food quality on consumer growth rate and elemental content. Ecology 2017, 98, 1399-1408. [CrossRef] [PubMed]

48. Sherman, R.E.; Chowdhury, P.R.; Baker, K.D.; Weider, L.J.; Jeyasingh, P.D. Genotype-specific relationships among phosphorus use, growth and abundance in Daphnia pulicaria. R. Soc. Open Sci. 2017, 4, 170770. [CrossRef] [PubMed] 
49. Lemmen, K.D.; Butler, O.M.; Koffel, T.; Rudman, S.M.; Symons, C.C. Stoichiometric traits vary widely within species: A meta-analysis of common garden experiments. Front. Ecol. Evol. 2019, 7, 1-15. [CrossRef]

50. Moe, S.J.; Stelzer, R.S.; Forman, M.R.; Harpole, W.S.; Daufresne, T.; Yoshida, T. Recent advances in ecological stoichiometry: Insights for population and community ecology. Oikos 2005, 109, 29-39. [CrossRef]

51. Nyffeler, M.; Bonte, D. Where have all the spiders gone? Observations of a dramatic population density decline in the once very abundant garden spider, Araneus diadematus (Araneae: Araneidae), in the Swiss Midland. Insects 2020, 11, 248. [CrossRef]

(C) 2020 by the authors. Licensee MDPI, Basel, Switzerland. This article is an open access article distributed under the terms and conditions of the Creative Commons Attribution (CC BY) license (http://creativecommons.org/licenses/by/4.0/). 